\title{
Rumen fermentation and production effects of Origanum vulgare L. leaves in lactating dairy cows
}

\author{
J. A. Tekippe, ${ }^{\star}$ A. N. Hristov, ${ }^{\star 1}$ K. S. Heyler, ${ }^{\star}$ T. W. Cassidy, ${ }^{\star}$ V. D. Zheljazkov,† J. F. S. Ferreira,‡ S. K. Karnati,§ \\ and G. A. Varga* \\ *Pennsylvania State University, University Park, PA 16802 \\ †Mississippi State University, North Mississippi Research and Extension Center (NMREC), Verona, MS 38879 \\ ‡USDA-Agricultural Research Service, Beaver, WV 25813 \\ $\S$ The Ohio State University, Columbus, $\mathrm{OH} 43210$
}

\section{ABSTRACT}

A lactating cow trial was conducted to study the effects of dietary addition of oregano leaf material (Origanum vulgare L.; OV; 0, control vs. 500 g/d) on ruminal fermentation, methane production, total tract digestibility, manure gas emissions, $\mathrm{N}$ metabolism, organoleptic characteristics of milk, and dairy cow performance. Eight primiparous and multiparous Holstein cows (6 of which were ruminally cannulated) were used in a crossover design trial with two 21 -d periods. Cows were fed once daily. The OV material was top-dressed and mixed with a portion of the total mixed ration. Cows averaged $80 \pm 12.5 \mathrm{~d}$ in milk at the beginning of the trial. Rumen $\mathrm{pH}$, concentration of total and individual volatile fatty acids, microbial protein outflow, and microbial profiles were not affected by treatment. Ruminal ammonia- $\mathrm{N}$ concentration was increased by OV compared with the control (5.3 vs. $4.3 \mathrm{mM}$ ). Rumen methane production, which was measured only within $8 \mathrm{~h}$ after feeding, was decreased by OV. Intake of dry matter (average of $26.6 \pm 0.83 \mathrm{~kg} / \mathrm{d}$ ) and apparent total tract digestibly of nutrients did not differ between treatments. Average milk yield, milk protein, lactose, and milk urea nitrogen concentrations were unaffected by treatment. Milk fat content was increased and 3.5\% fat-corrected milk yield tended to be increased by OV, compared with the control (3.29 vs. $3.12 \%$ and 42.4 vs. $41.0 \mathrm{~kg} / \mathrm{d}$, respectively). Fat-corrected $(3.5 \%)$ milk feed efficiency and milk net energy for lactation $\left(\mathrm{NE}_{\mathrm{L}}\right)$ efficiency (milk $\mathrm{NE}_{\mathrm{L}} \div \mathrm{NE}_{\mathrm{L}}$ intake) were increased by OV compared with the control (1.64 vs. $1.54 \mathrm{~kg} / \mathrm{kg}$ and 68.0 vs. $64.4 \%$, respectively). Milk sensory parameters were not affected by treatment. Urinary and fecal $\mathrm{N}$ losses, and manure ammonia and methane emissions were unaffected by treatment. Under the current experimental conditions, supplementation of dairy cow diets

Received December 14, 2010.

Accepted June 1, 2011.

${ }^{1}$ Correspondending author: anh13@psu.edu with $500 \mathrm{~g} / \mathrm{d}$ of OV increased milk fat concentration, feed and milk $\mathrm{NE}_{\mathrm{L}}$ efficiencies, and tended to increase $3.5 \%$ fat-corrected milk yield. The sizable decrease in rumen methane production with the OV supplementation occurred within $8 \mathrm{~h}$ after feeding and has to be interpreted with caution due to the large withinand between-animal variability in methane emission estimates. The OV was introduced into the rumen as a pulse dose at the time of feeding, thus most likely having larger effect on methane production during the period when methane data were collected. It is unlikely that methane production will be affected to the same extent throughout the entire feeding cycle.

Key words: oregano, methane, feed efficiency, dairy cow

\section{INTRODUCTION}

Many plants produce secondary metabolites, and although they are utilized by the plant for growth and reproduction, they may be useful in animal feeding because of their chemical activities (Wallace, 2004). Several thousand plant secondary metabolites have been reported (Kamra et al., 2006). Phenolic compounds, essential oils (EO), and sarsaponins, to name a few, have been shown to express antimicrobial activity (Cowan, 1999; Bakkali et al., 2008). As a result, secondary metabolites are being investigated as alternatives to antibiotics in animal nutrition (Greathead, 2003). Once identified, these compounds could be used to modify ruminal fermentation by enhancing the efficiency of utilization of feed energy while decreasing methane emission. In vitro screening of 450 plants yielded species capable of depressing methane production by more than $25 \%$ with no adverse effects on digestibility (Bodas et al., 2008). Similarly, Jayanegara et al. (2009) reported high inverse correlation between plant tannin content and methane production in vitro.

Origanum vulgare L. (oregano, $\mathbf{O V}$ ) is an herb with high antioxidant capacity, when compared with several 
other medicinal herbs (Dragland et al., 2003; Matsuura et al., 2003). The latter authors isolated 2 compounds from oregano leaves and named them oreganol $\mathrm{A}$ and oreganol B. Purified oreganol A had antioxidant activity similar to rosmarinic acid and quercetin and slightly higher than rutin. The primary constituents of OV EO are carvacrol, $\gamma$-terpinene, thymol, $p$-cimene, and linalool, depending on the origin and type of OV (Sivropoulou et al. 1996; Baser, 2002). Oregano EO were reported to have the second highest oxygen radical absorbance capacity (ORAC) value compared with clove (the highest), followed by cinnamon, ginger, and rosemary EO (Bentayeb et al., 2009). Thymol is a monoterpene with strong antimicrobial activity against a wide range of gram-positive and negative bacteria, and is one of the most researched active components of EO (Burt, 2004). Borchers (1965) was the first to report that the in vitro incubation of casein or microbial protein in rumen fluid with thymol $(1 \mathrm{mg} / \mathrm{mL})$ resulted in accumulation of AA and a decrease in ammonia- $\mathrm{N}$ concentration, suggesting that deamination was inhibited. Carvacrol is a phenolic compound similar to thymol found in OV that has strong antimicrobial activity. Busquet et al. (2005b) reported in vitro that carvacrol $(2.2 \mathrm{mg} / \mathrm{L})$ decreased large peptide concentrations and increased ammonia- $\mathrm{N}$ concentrations $2 \mathrm{~h}$ after feeding in long-term continuous culture of rumen contents. Wang et al. (2009) tested a commercial preparation of OV EO Ropadiar (Ropapharm Int., Zaandam, the Netherlands), advertised for veterinary use in various animals, and reported about $12 \%$ decrease in methane production in sheep, similar in magnitude to the effect of flavomycin, and Yucca schidigera saponins.

An in vitro screening experiment of a large set of EO and herbs identified OV leaf material as an antimethanogenic plant product with no adverse effects on ruminal fermentation or NDF degradability (Tekippe et al., 2010). Extrapolation of results from in vitro experiments to in vivo conditions, however, has limitations (Benchaar et al., 2009). Although in vitro experiments are useful in screening bioactive compounds for antimicrobial activity, the true value of these plant extracts for altering rumen microbial fermentation must be assessed in live animal trials.

Therefore, the hypothesis of this experiment, based on our in vitro results, was that inclusion of $\mathrm{OV}$ in the diet of dairy cows will decrease methane production with no adverse effect on nutrient digestibility or animal productivity. The specific objective of the study was to evaluate the effects of dietary supplementation of $500 \mathrm{~g}$ of OV leaf material/d on rumen fermentation and methane production, nutrient intake and digestibility, lactation performance, milk taste, and manure gas emissions in high-producing Holstein dairy cows.

\section{MATERIALS AND METHODS}

\section{Animals and Treatments}

The experiment was conducted under the approval of The Pennsylvania State University Animal Care and Use Committee (IACUC\# 29566) and involved 4 multiparous and 4 primiparous Holstein dairy cows averaging $41 \pm 2.6 \mathrm{~kg} / \mathrm{d}$ milk yield, $2.1 \pm 0.78$ lactations, and $80 \pm 10$ DIM at the beginning of the trial. The $\mathrm{OV}$ used in the experiment was grown in Greece and purchased from Ameriherb Inc. (Ames, IA). Six of the 8 cows were fitted with soft plastic ruminal cannulas (10.2 cm i.d.; Bar Diamond Inc., Parma, ID). Treatments were arranged in a crossover design with two 21-d periods. Each treatment group contained 4 cows including 3 ruminally cannulated. Cows were balanced across treatments based on DIM, current milk yield, and parity. Control cows received a basal TMR (Table 1) top-dressed with $500 \mathrm{~g} / \mathrm{d}$ of chopped fescue grass hay (Festuca arundinacea). Experimental cows received TMR top-dressed with $500 \mathrm{~g} / \mathrm{d}$ of OV. The fescue hay and OV were hand-mixed with a portion of the TMR during feeding. Although no specific measurements were collected, it was observed that cows consumed all OV offered. Cows were housed in a tie-stall facility and were fed once daily at approximately $0800 \mathrm{~h}$. Feed was pushed up 4 to 6 times daily. The basal diet was balanced to meet or exceed NRC (2001) requirements for lactating dairy cows weighing $640 \mathrm{~kg}$ and producing 44 $\mathrm{kg}$ of milk/d with $3.20 \%$ fat and $2.93 \%$ true protein. At the actual DMI of the cows, the basal diet exceeded the requirements for $\mathrm{NE}_{\mathrm{L}}$, but was slightly deficient in MP $(-67 \mathrm{~g} / \mathrm{d}$ for the control, or about $3 \%)$. All diets were fed ad libitum to achieve approximately $5 \%$ refusals. Cows had access to fresh water throughout the duration of the trial. During the trial, cows were milked daily at 0530 and $1730 \mathrm{~h}$ and received recombinant bST (rbST) at 14-d intervals (Posilac; Elanco Co., Greenfield, IN; $500 \mathrm{mg}$, i.m.) beginning at 63 DIM.

\section{Sampling and Analyses}

Feed intake was measured daily and TMR and refusal samples were collected twice weekly and composited by week. Total mixed ration and refusal samples were dried for $48 \mathrm{~h}$ at $65^{\circ} \mathrm{C}$ in a forced-air oven and then ground in a Wiley Mill (A. H. Thomas Co., Philadelphia, PA) through a 1-mm screen for chemical analyses. All TMR and refusal samples were then composited by period. Aliquot samples were pulverized at $30 \mathrm{~Hz} / \mathrm{s}$ for $2 \mathrm{~min}$ using Mixer Mill MM 200 (Retsch GmbH, Haan, Germany) for $\mathrm{N}$ analysis. Individual forages were sampled weekly and dried in a microwave oven to determine 
Table 1. Ingredient and chemical composition of the basal diet fed to cows during the trial

\begin{tabular}{|c|c|}
\hline Item & Diet \\
\hline \multicolumn{2}{|c|}{ Ingredient composition, $\%$ of DM } \\
\hline Corn silage $^{1}$ & 42.4 \\
\hline Alfalfa silage $^{2}$ & 13.1 \\
\hline Grass/straw hay & 4.4 \\
\hline Canola meal & 7.5 \\
\hline Bakery by-product ${ }^{3}$ & 6.6 \\
\hline Ground corn & 7.4 \\
\hline Cottonseed hulls & 10.8 \\
\hline Sugar blend ${ }^{4}$ & 4.2 \\
\hline Mineral/vitamin $\operatorname{mix}^{5}$ & 3.2 \\
\hline Optigen $^{6}$ & 0.4 \\
\hline \multicolumn{2}{|c|}{ Chemical composition, \% of DM or as indicated } \\
\hline $\mathrm{DM}, \%$ & 51.0 \\
\hline $\mathrm{CP}$ & 15.6 \\
\hline $\mathrm{ADF}$ & 20.5 \\
\hline aNDF & 32.0 \\
\hline $\mathrm{NFC}^{7}$ & 43.7 \\
\hline Ether extract ${ }^{7}$ & 3.8 \\
\hline $\mathrm{NE}_{\mathrm{L}}, \mathrm{Mcal} / \mathrm{kg}$ of $\mathrm{DM}^{8}$ & 1.54 \\
\hline $\mathrm{Ca}^{7}$ & 0.93 \\
\hline $\mathrm{P}^{7}$ & 0.39 \\
\hline
\end{tabular}

${ }^{1}$ Contained $32.2 \% \mathrm{DM}$ and (\%, DM basis): CP, 6.8; ADF, 25.1; amylase-treated NDF (aNDF), 40.0; NFC, 48.4; ether extract, 3.3; ash, 2.8; $\mathrm{Ca}, 0.15$; and $\mathrm{P}, 0.21$.

${ }^{2}$ Contained $47.3 \% \mathrm{DM}$ and (\%, DM basis): CP, 20.4; ADF, 30.6; aNDF, 39.7; NFC, 31.2; ether extract, 2.8; ash, 9.7; Ca, 1.22; and P, 0.30.

${ }^{3}$ Bakery by-product (Bakery Feeds Inc., Honey Brook, PA) contained (\%, DM basis): CP, 9.0; ether extract, 8.0; and crude fiber, 5.0.

${ }^{4}$ Sugar blend (Westway Feed Products LLC, Tomball, TX) contained (\%, DM basis) CP, 3.9, and total sugar, 66.0.

${ }^{5}$ Premix contained $0.29 \% \mathrm{~S}, 7.183 \mathrm{mg}$ of $\mathrm{Se} / \mathrm{kg}, 4.7 \mathrm{mg}$ of Co $/ \mathrm{kg}, 11.76$ $\mathrm{mg}$ of $\mathrm{I} / \mathrm{kg}, 21.1 \mathrm{mg}$ of vitamin $\mathrm{A} / \mathrm{kg}, 438.6 \mu \mathrm{g}$ of vitamin $\mathrm{D} / \mathrm{kg}$, and $685.9 \mathrm{mg}$ of vitamin $\mathrm{E} / \mathrm{kg}$.

${ }^{6}$ Optigen is a nonprotein N source $(243 \%$ CP, DM basis) from Alltech Inc. (Nicholasville, Kentucky).

${ }^{7}$ As analyzed by Cumberland Valley Analytical Services (Maugansville, MD).

${ }^{8}$ Estimated based on NRC (2001).

DM content. Weekly changes were made to the TMR, if changes occurred in forage DM content.

Rumen samples were collected on 2 consecutive days during wk 3 of each experimental period. Whole ruminal contents were collected at $0,2,4,6$, and $8 \mathrm{~h}$ after feeding from the ventral sac, atrium, and 2 samples from the feed mat. After mixing, an aliquot of the whole ruminal contents was frozen at $-20^{\circ} \mathrm{C}$ for bacterial, archaeal, and fungal profile analyses. The remaining sample was filtered through 2 layers of cheesecloth and the filtrate was immediately placed on ice for further analyses.

Eleven spot urine (approximately $300 \mathrm{~mL}$ each) and fecal (approximately $400 \mathrm{~g}$ each) samples were collected from each cow at 0900, 1500, and $2100 \mathrm{~h}$ on d 2; 0500, 1100 , and $1700 \mathrm{~h}$ on d 3; 0000, 0700, 1300, and $1900 \mathrm{~h}$ on $\mathrm{d} 4$; and at $0200 \mathrm{~h}$ on $\mathrm{d} 5$ of wk 3 of each experimental period. Urine samples were collected by massaging the vulva. Fecal samples were collected from the rectum or ground, if fresh. Urine was acidified $(\mathrm{pH}<3)$ using $2 M$ $\mathrm{H}_{2} \mathrm{SO}_{4}$; $\mathrm{pH}$ was verified using litmus paper. Acidified urine was diluted 1:10 with distilled water and stored frozen at $-20^{\circ} \mathrm{C}$. Fecal samples were oven dried at $65^{\circ} \mathrm{C}$ and composited per cow and period on an equal DM basis. Aliquots of fresh urine (unacidified) and feces were composited on a wet basis by cow and period and frozen immediately at $-20^{\circ} \mathrm{C}$ for later analysis of ammonia- and methane-emitting potential of manure.

Body weight was recorded for 3 consecutive days at the beginning and end of the trial and at the start of the second period. Cows were weighed using the AfiFarm 3.04E scale system (S.A.E. Afikim, Rehovot, Israel) while exiting the milk parlor.

Milk production was recorded daily, whereas samples for milk composition were collected 3 times during wk 3 of each experimental period. Dry matter intake and milk production from wk 3 were used in the statistical analysis and to calculate feed efficiency. Milk yield and DMI during the days of milk sampling (i.e., 3 times during wk 3 of each period) were used to calculate milk fat, protein, lactose, $\mathrm{NE}_{\mathrm{L}}$, and $3.5 \% \mathrm{FCM}$ yields, $3.5 \%$ FCM feed efficiency, and milk $\mathrm{NE}_{\mathrm{L}}$ efficiency. Morning and evening samples were analyzed separately so milk component concentration and yield could be weighed for a.m. and p.m. milk yields. Samples were preserved using 2-bromo-2-nitropropane-1,3-diol. The entire milk yield was collected from one consecutive night and morning milking, composited by treatment, and used for milk sensory panel evaluation.

Blood samples were collected from the coccygeal tail vein or artery $2 \mathrm{~h}$ after feeding. Blood samples were collected on 2 consecutive days during wk 3 of each trial period. Approximately $3 \mathrm{~mL}$ of blood was collected into an evacuated tube (Becton, Dickinson and Co., Franklin Lakes, NJ) containing $15 \mathrm{mg}$ of sodium fluoride and $12 \mathrm{mg}$ of potassium oxalate. At the same time, approximately $5 \mathrm{~mL}$ of blood was collected into an evacuated tube (Becton Dickinson) containing $0.79 \mathrm{mg}$ of sodium heparin. All tubes were placed immediately in ice and, within $1 \mathrm{~h}$, centrifuged at $4^{\circ} \mathrm{C}$ at $1,500 \times g$ for $15 \mathrm{~min}$. Plasma was recovered and frozen at $-20^{\circ} \mathrm{C}$ for future analyses.

Rumen cheesecloth filtrates were immediately analyzed for $\mathrm{pH}$ ( $\mathrm{pH}$ meter 59000-60 pH Tester; Cole-Parmer Instrument Co., Vernon Hills, IL) and processed for analyses of ammonia (Chaney and Marbach, 1962), VFA (Yang and Varga, 1989), total free AA (TFAA; ninhydrin procedure; Snell and Snell, 1954), and protozoal counts. Samples for protozoal enumeration were preserved (Hristov et al., 2001) and counted according to standard procedures (Dehority, 1993) using the Sedgewick-Rafter chamber (Hausser Scientific Co., Horsham, PA). 
The effect of $\mathrm{OV}$ on ruminal microbial populations was analyzed using 2 procedures: denaturing gradient gel electrophoresis (DGGE) analysis (Hristov et al., 2009) and tag-encoded FLX amplicon pyrosequencing (bTEFAP) using Gray28F 5'GAGTTTGATCNTGGCTCAG and Gray519r 5' GTNTTACNGCGGCKGCTG primers (Dowd et al., 2008a,b). Fungal tag-encoded FLX amplicon pyrosequence (fTEFAP) was performed using ITS1-ITS4 fungal primers, ITS1F 5'CTTGGTCATTTAGAGGAAGTAA ITS4R 5' TCCTCCGCTTATTGATATGC. Whole rumen content samples were composited per cow and period and used for these analyses. For the DGGE procedure, DNA was extracted using the $\mathrm{RBB}+\mathrm{C}$ method ( $\mathrm{Yu}$ and Morrison, 2004); PCR thermoprofiles, DGGE conditions, and cluster analysis of the banding patterns were as explained before (Hristov et al., 2009). Tag-encoded FLX amplicon pyrosequencing analyses used a Roche 454 FLX instrument with titanium reagents (Roche Diagnostics Corp., Indianapolis, IN), titanium procedures, a 1-step PCR, mixture of Hot Start and HotStar high fidelity Taq polymerases (Qiagen Inc., Valencia, $\mathrm{CA}$ ), and amplicons originating and extending from the $28 \mathrm{~F}$ for bacterial diversity and ITS1 for fungal diversity. The bTEFAP pyrosequencing were based upon titanium protocols (Roche Diagnostics Corp.) and procedures were performed at the Research and Testing Laboratories (Lubbock, TX) based upon ready-to-load protocols (http://www.researchandtesting.com).

Methane production in the rumen was measured using the sulfur hexafluoride $\left(\mathrm{SF}_{6}\right)$ tracer technique (Johnson et al., 1994). The $\mathrm{SF}_{6}$ permeation tubes were purchased from Keith Lassey (National Institute of Water and Atmospheric Research, Wellington, NZ). The tubes had an average $\mathrm{SF}_{6}$ release rate of $3.04 \pm$ $0.131 \mathrm{mg} / \mathrm{d}$, were placed in the reticulum of the cows on $\mathrm{d} 1$ of the experiment, and remained there throughout the duration of the study. Rumen gas samples were collected directly from the rumen through a modified rumen cannula (for description see Hristov et al., 2009) placed in $3 \mathrm{~h}$ before gas collection. Gas samples were collected at $0,2,4,6$, and $8 \mathrm{~h}$ after feeding during 1 day of wh 3 of each experimental period. A $60-\mathrm{mL}$ syringe was used to remove $110 \mathrm{~mL}$ of rumen gas into a $100-\mathrm{mL}$ vacuumed serum bottle. Bottles were refrigerated until analyzed for methane and $\mathrm{SF}_{6}$ using GLC (Hristov et al., 2009). Production of methane was calculated as the release rate of $\mathrm{SF}_{6}$ times the ratio of the concentration of methane to $\mathrm{SF}_{6}$ in the ruminal headspace (Johnson et al., 1994).

Ammonia-, methane-, and nitrous oxide-emitting potentials of manure were analyzed in a steady-state gas emission system (Wheeler et al., 2007) as described by Hristov et al. (2009). Gases were analyzed on a photoacoustic gas analyzer (INNOVA Model 1412; AirTech Instruments A/S Co., Ballerup, Denmark).

Dry matter intake was calculated by adjusting daily as-fed feed intake to DM content (measured for $48 \mathrm{~h}$ at $65^{\circ} \mathrm{C}$ ) of the weekly diet and refusals composited samples. Diet, refusals, and fecal composited samples were analyzed for amylase-treated NDF (aNDF) and ADF using the Ankom ${ }^{200}$ Fiber Analyzer (Ankom Technology Corp., Macedon, NY) according to Van Soest et al. (1991) with heat stable amylase (Ankom Technology Corp.) and sodium sulfite (Fisher Scientific, Waltham, MA) used in the aNDF procedure. Nitrogen content for diet, refusals, fecal, and urine were analyzed on a Costech ECS 4010 C/N/S elemental analyzer (Costech Analytical Technologies Inc., Valencia, CA) and multiplied by 6.25 to obtain $\mathrm{CP}$ values. Total nonstructural carbohydrates were analyzed on fecal and diet samples that were reground to pass through a $0.5-\mathrm{mm}$ screen, and analyzed using a procedure described by Smith (1981) with the modification to use potassium ferriccyanide as a colorimetric indicator.

Apparent total tract digestibility of nutrients was estimated using indigestible NDF as an intrinsic digestibility marker (Foley et al., 2006). Indigestible NDF in feed and fecal samples was analyzed according to Huhtanen et al. (1994), with the exception that 25- $\mu \mathrm{m}$ pore size Ankom filter bags were used for the rumen incubation. Diet, refusals, and fecal samples were ashed for $4 \mathrm{~h}$ at $600^{\circ} \mathrm{C}$ for analysis of $\mathrm{OM}$.

Blood plasma samples were analyzed for glucose (Sigma Glucose Kit 510; Sigma Chemical Co., St. Louis, MO) and plasma urea N (PUN; Stanbio Urea Nitrogen Kit 580; Stanbio laboratory Inc., San Antonio, TX).

Urinary purine derivatives (allantoin and uric acid) excretion was used to estimate duodenal microbial $\mathrm{N}$ flow (for equations see Hristov et al., 2009). A ratio of purine $\mathrm{N}$ to total $\mathrm{N}$ in rumen microorganisms of 0.134 was assumed based on the data of Valadares et al. (1999).

Milk samples were analyzed for fat, true protein, lactose, and MUN (Pennsylvania DHIA, University Park, PA) using infrared spectroscopy (MilkoScan 4000; Foss Electric, Hillerød, Denmark). Organoleptic properties of milk were evaluated by a 48-subjects sensory panel. A balanced reference duo-trio test was used to determine if the OV milk was significantly different from the control milk. Panelists were presented with 3 cups: 2 controls and 1 OV milk sample labeled with 3 -digit blinding codes and a labeled reference, which was either the control or OV sample. The presentation order was counterbalanced with the reference being presented in the left position and panelists were instructed to 
identify the coded sample that was the same as the reference. Water and saltine crackers were provided as palate cleansers. Evaluations took place in individual testing booths using Compusense five software (release 4.6; Compusense Inc., Guelph, ON, Canada).

Representative samples of OV (250 g of dried material in 3 replicates) were steam distilled for $60 \mathrm{~min}$ in 2-L Clevenger-type distillation units as described elsewhere (Zheljazkov et al., 2008). Extracted EO was analyzed by GC-MS on a Varian CP-3800 GC coupled to a Varian Saturn 2000 MS/MS (Varian Inc., Palo Alto, CA) and methods of Kovats (1965) and Adams (2009). The GC was equipped with a DB-5 fused silica capillary column $(30 \mathrm{~m} \times 0.25 \mathrm{~mm}$, film thickness of $0.25 \mu \mathrm{m})$. The injector temperature was $240^{\circ} \mathrm{C}$ and the column temperature was initiated at $60^{\circ} \mathrm{C}$, increased at $3^{\circ} \mathrm{C} / \mathrm{min}$ to $240^{\circ} \mathrm{C}$, and held for $5 \mathrm{~min}$. The carrier gas was $\mathrm{He}$ and the injection volume was $1 \mu \mathrm{L}$ (10:1 split). The MS conditions were mass range of 40 to $650 \mathrm{~m} / \mathrm{z}$, filament delay of $3 \mathrm{~min}$, target TIC of 20,000, pre-scan ionization time of $100 \mu \mathrm{s}$, ion trap temperature of $150^{\circ} \mathrm{C}$, manifold temperature of $60^{\circ} \mathrm{C}$, and a transfer line temperature of $170^{\circ} \mathrm{C}$. Essential oil constituents were each identified by first determining their Kovats index using previously reported methods (Kovats, 1965) and comparison of mass spectrum with that reported by Adams (2009). Final confirmation was accomplished by comparison of retention times and mass spectra data with authentic standards when needed. Carbon 13 NMR data was used in the confirmation of carvacrol due to the Kovats index and mass spectrum similarities with thymol. Essential oil constituents were quantified by performing area percentage calculations based on the total ion chromatogram combined area. For example, the area for each reported peak was divided by the total integrated area from the total ion chromatogram from all reported peaks and multiplied by 100 to arrive at a percentage. The reported percentage is a percentage by weight in the extracted EO.

For quantification of antioxidant capacity of OV, the ORAC assay was used (Prior et al., 2003). Three samples of approximately $250 \mathrm{mg}$ of OV leaves were weighed and extracted with hexane by sonication, twice. The hexane fractions were combined and used to quantify ORAC of the lipophilic fraction $\left(\mathrm{ORAC}_{\text {lipo }}\right)$. The same samples, after hexane extraction, were then extracted with $70 \%$ acetone (30\% water; vol/vol) and acidified with $0.5 \%$ glacial acetic acid, with sonication for $20 \mathrm{~min}$, twice. The fractions were combined and analyzed for hydrophilic components of the antioxidant capacity $\left(\mathrm{ORAC}_{\text {hydro }}\right)$. Samples were analyzed with 4 $\left(\mathrm{ORAC}_{\text {hydro }}\right)$ or $3\left(\mathrm{ORAC}_{\text {lipo }}\right)$ replicates and quantified using a standard curve (using Trolox, a vitamin
E water-soluble equivalent; Hoffmann-La Roche Ltd., Basel, Switzerland) run in the same plate. The results are expressed in $\mu \mathrm{mol}$ of Trolox equivalents $(\mathbf{T E}) / \mathrm{g}$ of dry plant material.

\section{Statistical Analysis}

Data were analyzed using the PROC MIXED procedure of SAS (SAS Institute, 2003). Nutrient intake, digestibility, rumen TFAA, protozoal counts, and microbial data, urinary excretions, and cow BW data were analyzed assuming a crossover design. The model used was

$$
Y_{i j k l}=\mu+g_{i}+c(g)_{i j}+P_{k}+T_{l}+e_{i j k l}
$$

where $Y_{i j k l}$ is the dependent variable, $\mu$ is the overall mean, $g_{i}$ is the group, $c(g)_{i j}$ is the cow within group, $P_{k}$ is the $k$ th period, $T_{l}$ is the lth treatment, with the error term $e_{i j k l}$ assumed to be normally distributed with mean $=0$ and constant variance. Group and cow within group were random effects and all others were fixed.

Ruminal fermentation data ( $\mathrm{pH}$, ammonia, VFA concentrations, and methane production rate), DMI, milk yield, milk composition, yields of milk fat, protein, lactose, $\mathrm{NE}_{\mathrm{L}}$, and $3.5 \% \mathrm{FCM}, 3.5 \% \mathrm{FCM}$ feed efficiency, and milk $\mathrm{NE}_{\mathrm{L}}$ efficiency were analyzed as repeated measures assuming a crossover design and an $\operatorname{ar}(1)$ covariance structure. The model used was

$$
\begin{aligned}
Y_{i j k l m} & =\mu+g_{i}+c(g)_{i j}+P_{k}+T_{l} \\
& +D_{m}+T D_{l m}+e_{i j k l m},
\end{aligned}
$$

where $Y_{i j k l m}$ is the dependent variable, $\mu$ is the overall mean, $g_{i}$ is the group, $c(g)_{i j}$ is the cow within group, $P_{k}$ is the $k$ th period, $T_{l}$ is the $l$ th treatment, $D_{m}$ is the time effect, $T D_{l m}$ is the treatment $\times$ time of sampling interaction, with the error term $e_{i j k l m}$ assumed to be normally distributed with mean $=0$ and constant variance. Group and cow within group were random effects and all others were fixed. Only significant interactions are published and discussed.

Cumulative ammonia and methane emissions from manure data were fitted (PROC NLIN; SAS) to a quadratic model: $\left(\mathrm{a}+\mathrm{b} \times\right.$ time $+\mathrm{c} \times$ time $^{2}$; adjusted $\mathrm{R}^{2}$ was $>0.99$ for all data sets). Estimated overall emission lines were compared between treatments using the dummy variable regression technique (PROC NLMIXED, SAS; Bates and Watts, 1988).

Statistical differences were declared at $P<0.05$. Differences between treatments at $0.05<P<0.10$ were considered as a trend toward significance. 
Table 2. Chemical composition ${ }^{1}$ of Origanum vulgare L. and fescue hay used in the study

\begin{tabular}{lcc}
\hline Item & $\begin{array}{c}\text { Fescue } \\
\text { hay }\end{array}$ & $\begin{array}{c}\text { Origanum } \\
\text { vulgare } \mathrm{L} .\end{array}$ \\
\hline DM, \% & 89.3 & 89.9 \\
Composition, \% of DM & & \\
CP & 5.8 & 10.9 \\
ADF & 47.0 & 22.2 \\
aNDF & 75.2 & 31.9 \\
NFC & 14.7 & 46.6 \\
Ether extract & 2.0 & 1.4 \\
Starch & 2.3 & 8.5 \\
Ash & 4.2 & 9.2 \\
Ca & 0.3 & 2.1 \\
P & 0.1 & 0.1 \\
\hline
\end{tabular}

${ }^{1}$ As analyzed by Cumberland Valley Analytical Services (Maugansville, MD).

${ }^{2}$ Amylase-treated NDF.

\section{RESULTS}

Diet ingredient changes were not made throughout this trial and forages remained the same. The chemical compositions of OV and the fescue hay are shown in Table 2. The fescue hay had higher concentrations of fiber and lower CP and NFC than did OV. At $26 \mathrm{~kg}$ of DMI/d and $500 \mathrm{~g} / \mathrm{d}$ supplement inclusion rate, however, this difference would have little effect on ruminal fermentation or cow performance.

The main compound of the oregano EO was carvacrol (Table 3). Carvacrol represented $91 \%$ of the EO, which classifies the OV used in this study as carvacrol-type, based on Baser (2002). Gama-terpinene is commonly found in oregano EO (Baser, 2002) and represented around $2.3 \%$ in this EO. Thymol and linalool (a major terpene in oregano $\mathrm{EO}$ ) were not detected.

Oregano leaves used in this study had a total ORAC $\left(\right.$ ORAC $_{\text {TAC }}$ ) of $2,082 \mu \mathrm{mol} \mathrm{TE} / \mathrm{g}$ of dry plant material. The ORAC $_{\text {TAC }}$ is the sum of the ORAC lipo $_{\text {lus }}$ plue OR$\mathrm{AC}_{\text {hydro }}$. Although specific antioxidant components of oregano were not analyzed, the lipophilic fraction usually contains $\mathrm{EO}$ components, vitamins $\mathrm{E}$ and $\mathrm{A}$, and other fat-soluble components. The average $\mathrm{ORAC}_{\text {lipo }}$ was $41 \mu \mathrm{mol}$ of $\mathrm{TE} / \mathrm{g}$, whereas the average $\mathrm{ORAC}_{\text {hydro }}$ (usually containing flavonoids and other polar components) was 2,041 $\mathrm{mol}$ of $\mathrm{TE} / \mathrm{g}$.

Treatment had no effect on rumen $\mathrm{pH}$, concentrations of total and individual VFA, TFAA, and protozoa counts (Table 4). A trend existed for increased acetateto-propionate ratio $(P=0.10)$ for cows supplemented with OV. The ammonia-N concentration was increased $(P<0.001)$ in the OV treatment. No treatment by time interactions were observed for $\mathrm{pH}$, ammonia, or total and individual VFA. The average methane production in the rumen was decreased $40 \%$ (average over the sampling period; $P=0.004$ ) over the 8 -h sampling period by OV compared with the control. A treatment by time interaction was found for methane production rate $(P<0.05$; Figure 1$)$. Except for the initial sample $(2 \mathrm{~h})$ after feeding, the average methane production was consistently lower for OV than the control throughout the sampling period.

Results from the DGGE analysis are shown in Figure 2. Samples tended to cluster mostly by experimental period and treatment had no effect on the DGGE banding patterns. Bacteroidaceae and Clostridiales were predominant bacteria in the rumen, constituting more than $35 \%$ of the total bacterial population (based on the pyrosequencing analysis; Table 5). Clostridium spp. were increased $(P=0.003)$ and Bacteroidaceae were decreased $(P=0.03$; although Bacteroides were increased) by OV compared with the control. Species such as Ruminococcus albus and Prevotella ruminicola, considered typical ruminal bacteria, were detected in low levels. No significant differences were observed in the archaeal populations. Methanobacteriaceae were the predominant methanogens in these samples constituting around $60 \%$ of all archaea. Neocallimastix spp. were the predominant fungi (data not shown) and treatment had no effect on their proportion of the total fungal population in the rumen (27 and $23 \%$, control and OV, respectively; $P=0.71)$.

Intake of DM (Table 6) and dietary nutrients (data not shown) were not affected by treatment. Apparent total tract digestibility of DM (63\%), OM (64\%), CP (59\%), aNDF (34\%), ADF (29\%) and total nonstructural carbohydrates (91\%) were also not affected by OV $(P=0.62$ to 0.98 ; data not shown). Cow BW, milk yield, milk $\mathrm{NE}_{\mathrm{L}}$ output, and milk protein, lactose, and

Table 3. Composition of essential oil extracted from Origanum vulgare L. leaves used in the study (average of 3 replicated analyses)

\begin{tabular}{|c|c|}
\hline Compound & $\begin{array}{c}\text { Concentration, } \\
\% \text { of total } \\
\text { essential oil }\end{array}$ \\
\hline Carvacrol & $90.8^{2}$ \\
\hline$\gamma$-Terpinene & 2.34 \\
\hline$\delta$-Amorphene & 1.50 \\
\hline$\beta$-Caryopyllene & 0.81 \\
\hline$\alpha$-Guainene & 0.72 \\
\hline p-Cymene & 0.48 \\
\hline Borneol & 0.48 \\
\hline$\tau$-Cadinol & 0.32 \\
\hline Trans-sabinene hydrate & 0.27 \\
\hline Spathulenol & 0.23 \\
\hline Carvacrol acetate & 0.23 \\
\hline Caryophyllene oxide & 0.18 \\
\hline$\gamma$-Cadinene & 0.11 \\
\hline$\delta$-Cadinene & 0.12 \\
\hline Manool oxide & 0.09 \\
\hline Unknown & 1.59 \\
\hline
\end{tabular}

${ }^{1}$ Essential oil represented $1.4 \%$ oregano leaves DM.

${ }^{2} \mathrm{n}=3, \mathrm{SE}=4.1$. 


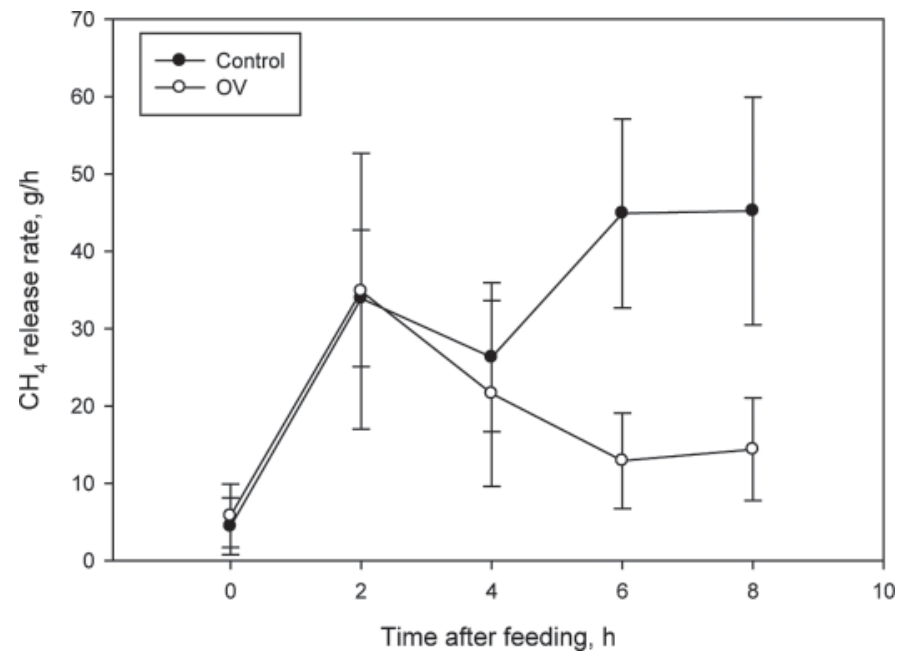

Figure 1. Effect of Origanum vulgare L. supplementation (OV; 500 $\mathrm{g} / \mathrm{d}$ ) on rumen methane production rate in dairy cows (mean $\pm \mathrm{SE}$; $\mathrm{n}=50$; number of observations used in the statistical analysis; effect of treatment, $P=0.004$; effect of time, $P=0.02$; treatment $\times$ time interaction, $P=0.05)$.

MUN concentrations were not affected by treatment. A numerical trend $(P=0.11)$ existed for increased feed efficiency for the OV-supplemented cows. Milk fat content and yield and 3.5\% FCM feed efficiency were increased $(P=0.02$ to 0.001$)$ for cows fed OV compared with the control. Yield of $3.5 \%$ FCM tended to be increased $(P=0.09)$ by OV compared with the control. The efficiency of conversion of feed $\mathrm{NE}_{\mathrm{L}}$ into milk $\mathrm{NE}_{\mathrm{L}}\left(\right.$ milk $\mathrm{NE}_{\mathrm{L}} \div \mathrm{NE}_{\mathrm{L}}$ intake) was increased $(P$ $=0.004$ ) by OV compared with the control (Table 6 ).
Participants in the milk sensory panel were asked to identify which coded milk sample was the same as the presented reference milk under the duo-trio test design. Of the 48 total responses collected, 31 correct responses were required to establish significance at $\alpha=$ 0.05. Sensory results showed that milk from cows fed OV was not different from the control, as it received only 26 correct responses $(P=0.33 ; \mathrm{n}=48)$.

Urinary excretions of allantoin and uric acid were not affected by treatment (Table 7). As a result, estimated microbial $\mathrm{N}$ flow from the rumen was also not different between treatments. Bacterial purine:total $\mathrm{N}$ ratio was not analyzed in this experiment. The basal TMR was identical for the 2 treatments and it was assumed that the purine:total $\mathrm{N}$ ratio in ruminal bacteria would be similar between treatments in this experiment. Contrastingly different diets (barley- vs. cornbased) produced similar bacterial purine:total $\mathrm{N}$ ratios (Hristov et al., 2005a). It is possible, however, that the $\mathrm{OV}$ treatment affected bacterial purine:total $\mathrm{N}$ ratio and this was not accounted for in our microbial flow estimates. Urinary and urea $\mathrm{N}$ excretions tended to be decreased by OV compared with the control. Absolute and relative (to intake) fecal and total $\mathrm{N}$ losses were unaffected by treatment. Absolute milk N secretion was also not affected by treatment, but the proportion of $\mathrm{N}$ intake (i.e., milk $\mathrm{N}$ efficiency) was greater $(P=0.04)$ for OV compared with the control. The concentration of PUN was increased $(P=0.05)$ by OV compared with the control. Plasma glucose concentrations were similar between treatments (data not shown).

Table 4. Ruminal fermentation characteristics of cows fed control or Origanum vulgare L. (OV)-supplemented diets $\left[\mathrm{pH}\right.$, ammonia, and VFA, $\mathrm{n}=60^{1}$; protozoal counts and total free AA (TFAA), $\mathrm{n}=12$; methane production, $\left.\mathrm{n}=50^{2}\right]$

\begin{tabular}{lcccc}
\hline Item & Control & $\mathrm{OV}^{3}$ & SEM & $P$-value \\
\hline $\mathrm{pH}$ & 6.0 & 6.1 & 0.09 & 0.47 \\
Ammonia, $\mathrm{m} M$ & 4.5 & 5.5 & 0.46 & $<0.001$ \\
TFAA, m $M$ & 3.1 & 3.0 & 0.57 & 0.81 \\
VFA, $\mathrm{m} M$ & & & & \\
Total & 132.2 & 128.9 & 6.64 & 0.28 \\
Acetate & 80.8 & 79.7 & 2.25 & 0.20 \\
Propionate & 30.5 & 28.4 & 1.73 & 0.15 \\
Butyrate & 14.2 & 14.5 & 0.34 & 0.37 \\
Isobutyrate & 1.12 & 1.15 & 0.05 & 0.45 \\
Valerate & 3.24 & 2.77 & 0.32 & 0.14 \\
Isovalerate & 2.32 & 2.35 & 0.10 & 0.50 \\
Acetate:propionate & 2.72 & 2.86 & 0.29 & 0.10 \\
Protozoa, $\times 10^{5} / \mathrm{mL}$ & 2.9 & 3.0 & & \\
Log protozoa & 5.4 & 5.4 & 0.06 & 0.59 \\
Methane production ${ }^{4}{ }^{\mathrm{g}} / \mathrm{h}$ & 31.2 & 18.8 & 8.21 & 0.004 \\
\hline
\end{tabular}

${ }^{1}$ Represents number of observations used in the statistical analysis.

${ }^{2}$ Measurements for $1 \mathrm{cow}$ on the control treatment were lost during period 1 of the trial. Another 4 individual time point measurements were also lost and 1 observation was removed as an outlier based on an absolute studentized residual value $>3$ (PROC REG of SAS); thus, $\mathrm{n}=50$.

${ }^{3} \mathrm{OV}=500 \mathrm{~g}$ of $\mathrm{OV} / \mathrm{d}$.

${ }^{4}$ Data collected within $8 \mathrm{~h}$ after feeding. Treatment $\times$ time interaction, $P=0.05$ (see Figure 1). 
Table 5. Predominant (as $\%^{1}$ of total isolates) bacteria and archaea in whole ruminal contents of dairy cows fed control or Origanum vulgare L. (OV)-supplemented diets $\left(\mathrm{n}=12^{2}\right)$

\begin{tabular}{|c|c|c|c|c|}
\hline Microorganism & Control & $\mathrm{OV}^{3}$ & SEM & $P$-value \\
\hline \multicolumn{5}{|l|}{ Bacteria } \\
\hline Eubacterium & 2.9 & 2.8 & 0.41 & 0.93 \\
\hline Lachnospiraceae & 7.3 & 8.5 & 1.82 & 0.32 \\
\hline Ruminococcus & 3.1 & 3.0 & 0.85 & 0.76 \\
\hline Ruminococcus albus & 0.4 & 0.3 & 0.14 & 0.87 \\
\hline Prevotella & 2.7 & 2.7 & 0.38 & 0.93 \\
\hline Prevotella ruminicola & 1.5 & 1.0 & 0.49 & 0.34 \\
\hline Butyrivibrio fibrisolvens & 1.6 & 1.9 & 0.39 & 0.07 \\
\hline Succiniclasticum ruminis & 1.6 & 2.5 & 0.48 & 0.20 \\
\hline Clostridiales & 14.9 & 15.9 & 2.77 & 0.64 \\
\hline Clostridium & 6.6 & 7.6 & 1.13 & 0.003 \\
\hline Bacteroidaceae & 26.8 & 20.3 & 5.71 & 0.03 \\
\hline Bacteroides & 2.8 & 3.6 & 0.78 & 0.002 \\
\hline \multicolumn{5}{|l|}{ Archaea } \\
\hline Euryarchaeota & 16.0 & 17.9 & 1.99 & 0.30 \\
\hline Methanobrevibacter & 18.6 & 20.6 & 1.31 & 0.38 \\
\hline Methanobacteriaceae & 61.5 & 58.9 & 2.94 & 0.48 \\
\hline
\end{tabular}

${ }^{1}$ The $\%$ represents the percentage of the total sequences analyzed within the sample.

${ }^{2}$ Represents number of observations used in the statistical analysis.

${ }^{3} \mathrm{OV}=500 \mathrm{~g}$ of $\mathrm{OV} / \mathrm{d}$.

The ammonia- and methane-emitting potentials of manure were not affected by treatment $(P=0.76$ and $P=0.67$, respectively; data not shown). Nitrous oxide concentration in manure gas was negligible (around 0.6 $\left.\mathrm{mg} / \mathrm{m}^{3}\right)$.

\section{DISCUSSION}

The OV material used in the current experiment was selected based on in vitro incubations of EO and plant materials (Tekippe et al., 2010). In this in vitro batch culture screening study, herbs and EO were evaluated

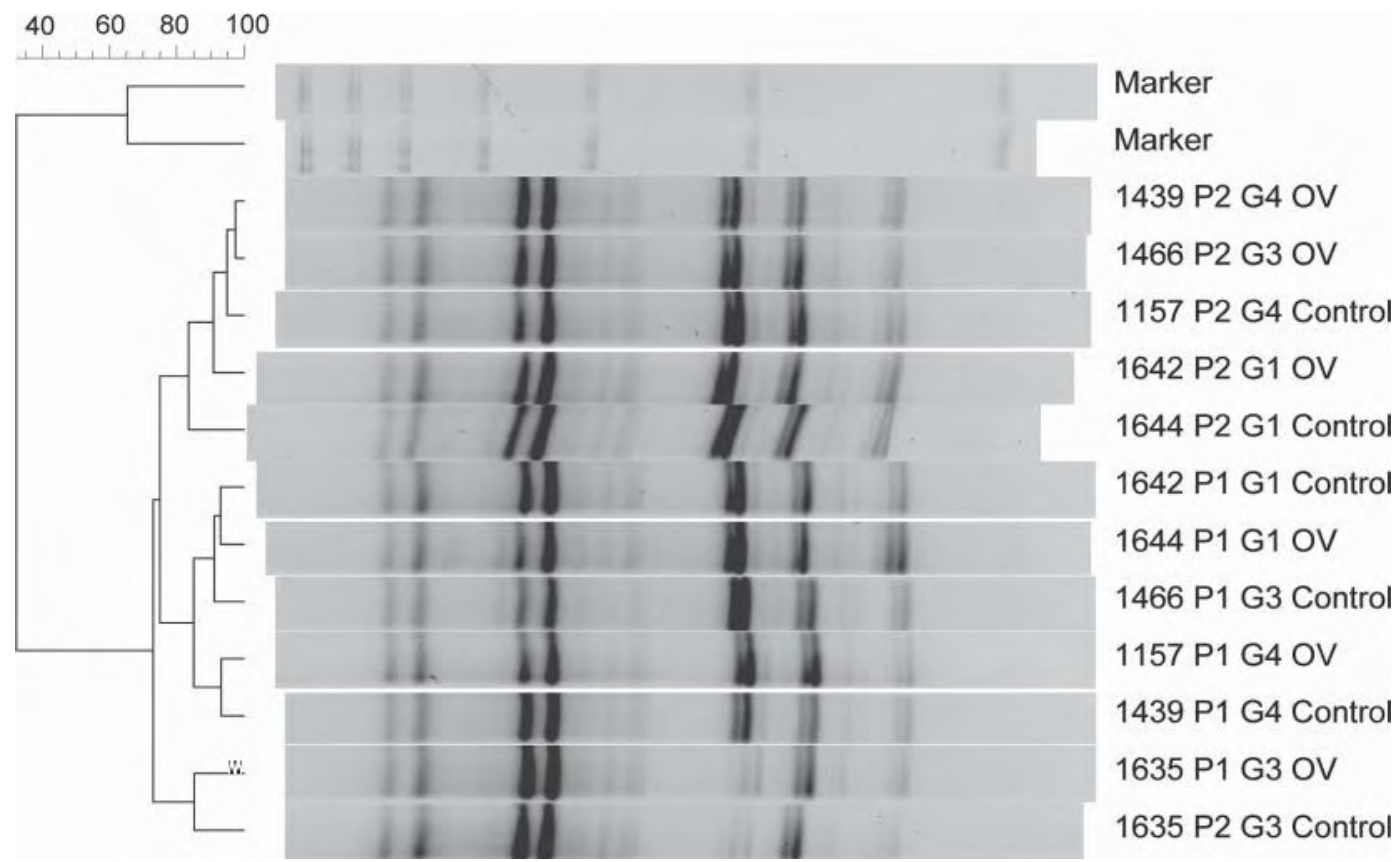

Figure 2. Denaturing gradient gel electrophoresis profiles of methanogens produced from community DNA samples from whole ruminal contents from cows fed control or Origanum vulgare L. (OV; $500 \mathrm{~g} / \mathrm{d}$ )-supplemented diets. The lanes are labeled with the cow number, period number, group number, and treatment. The calculated similarity coefficients determined using BioNumerics software (Applied Math Inc., Austin, TX) are shown on the top left-hand side $(\mathrm{n}=12)$. 
Table 6. Dry matter intake and production parameters of cows fed control or Origanum vulgare L. (OV)supplemented diets (DMI, milk yield, and feed efficiency, $\mathrm{n}=112^{1}$; BW, $\mathrm{n}=16$; all other variables, $\mathrm{n}=48^{2}$

\begin{tabular}{|c|c|c|c|c|}
\hline Item & Control & $\mathrm{OV}^{3}$ & SEM & $P$-value \\
\hline DMI, kg/d & 26.7 & 26.0 & 3.01 & 0.24 \\
\hline Milk, kg/d & 43.6 & 44.1 & 3.58 & 0.61 \\
\hline Feed efficiency ${ }^{4}$ & 1.66 & 1.72 & 0.066 & 0.11 \\
\hline Milk fat, $\%$ & 3.12 & 3.29 & 0.281 & 0.02 \\
\hline Fat yield, $\mathrm{kg} / \mathrm{d}$ & 1.37 & 1.45 & 0.210 & 0.01 \\
\hline Milk true protein, $\%$ & 2.97 & 2.96 & 0.098 & 0.53 \\
\hline Protein yield, kg/d & 1.30 & 1.30 & 0.149 & 0.92 \\
\hline Milk lactose, \% & 4.77 & 4.75 & 0.052 & 0.43 \\
\hline Lactose yield, $\mathrm{kg} / \mathrm{d}$ & 2.07 & 2.08 & 0.193 & 0.84 \\
\hline MUN, mg/100 mL & 13.4 & 13.3 & 0.841 & 0.91 \\
\hline $3.5 \% \mathrm{FCM}, \mathrm{kg} / \mathrm{d}$ & 41.0 & 42.4 & 4.83 & 0.09 \\
\hline $3.5 \%$ FCM feed efficiency & 1.54 & 1.64 & 0.034 & 0.001 \\
\hline Milk $\mathrm{NE}_{\mathrm{L}}, \mathrm{Mcal} / \mathrm{d}$ & 28.2 & 29.0 & 3.43 & 0.17 \\
\hline Dietary $\mathrm{NE}_{\mathrm{L}}$ intake, Mcal/d & 43.8 & 42.8 & 5.07 & 0.32 \\
\hline Milk $\mathrm{NE}_{\mathrm{L}}$ efficiency ${ }^{5}$ & 64.4 & 68.0 & 1.26 & 0.004 \\
\hline Cow BW, kg & 640 & 640 & 46.2 & 0.97 \\
\hline
\end{tabular}

${ }^{1}$ Represents number of observations used in the statistical analysis.

${ }^{2}$ Milk yield, DMI, and milk composition data from 3 milk samplings during wk 3 of each experimental period were used to calculate component and milk $\mathrm{NE}_{\mathrm{L}}$ yields and $3.5 \% \mathrm{FCM}$ feed and milk $\mathrm{NE}_{\mathrm{L}}$ efficiencies.

${ }^{3} \mathrm{OV}=500 \mathrm{~g}$ of $\mathrm{OV} / \mathrm{d}$.

${ }^{4}$ Milk $\div$ DMI.

${ }^{5}$ Milk $\mathrm{NE}_{\mathrm{L}} \div \mathrm{NE}_{\mathrm{L}}$ intake.

as potential anti-methanogenic additives for ruminant diets. A total of $88 \mathrm{EO}$ and 14 herbs were tested. Origanum vulgare L. leaf material was among the most effective anti-methanogenic additives and had no adverse effect on VFA production and in vitro NDF digestibility. In this screening experiment, 4 levels of OV were tested; the highest level, $5,000 \mathrm{mg} / \mathrm{L}$, decreased $(P=$ 0.003 ) methane production by about $54 \%$ compared with the blank. Compared with the blank, all levels of
OV increased $(P<0.001)$ the 24 -h NDF digestibility (24.8 vs. 27.6 to $30.0 \%$, respectively). Therefore, the $5,000 \mathrm{mg} / \mathrm{L}$ OV application level, which would correspond to $500 \mathrm{~g}$ of $\mathrm{OV} / \mathrm{cow}$ per day for a 100-L rumen volume (assuming all OV was immediately consumed), was chosen for the current experiment.

Overall, the reported effects of EO and plant products on ruminal fermentation have been very inconsistent, which is not surprising given the large variability

Table 7. Estimated ruminal microbial protein outflow from the rumen and $\mathrm{N}$ losses in dairy cows fed control or Origanum vulgare L. (OV)-supplemented diets $\left(\mathrm{n}=16^{1}\right)$

\begin{tabular}{lcccc}
\hline Item & Control & $\mathrm{OV}^{2}$ & SEM & $P$-value \\
\hline Urinary purine derivatives excretion, $\mathrm{m} M$ /d & & & & \\
Allantoin & 413 & 378 & 60.7 & 0.47 \\
Uric acid & 86 & 78 & 9.3 & 0.18 \\
Total purine derivatives & 498 & 456 & 68.6 & 0.39 \\
Microbial N flow, g/d & 333 & 302 & 49.3 & 0.39 \\
Urinary and fecal N excretion & & & & \\
Urine N, g/d & 240 & 230 & 20.0 & 0.06 \\
Urine N, \% of N intake & 32.2 & 31.5 & 0.66 & 0.48 \\
Urea N, g/d & 663 & 590 & 8.31 & 0.05 \\
Urea N, \% of urine N & 27.2 & 26.0 & 0.98 & 0.35 \\
Fecal N, g/d & 290 & 280 & 40.0 & 0.42 \\
Fecal N, \% of N intake & 40.4 & 41.9 & 3.19 & 0.53 \\
Total N excretion, g/d & 530 & 510 & 40.0 & 0.42 \\
Total N excretion, \% of N intake & 72.6 & 73.4 & 3.33 & 0.78 \\
Milk protein N, ${ }^{3}$, $/ \mathrm{d}$ & 0.20 & 0.20 & 0.023 & 0.92 \\
Milk protein N, \% of N intake & 27.7 & 28.5 & 0.36 & 0.04 \\
PUN, mg/100 mL & 8.8 & 9.5 & 0.28 & 0.05 \\
\hline
\end{tabular}

${ }^{1}$ Represents number of observations used in the statistical analysis.

${ }^{2} \mathrm{OV}=500 \mathrm{~g}$ of $\mathrm{OV} / \mathrm{d}$.

${ }^{3}$ Milk $\mathrm{N}=$ true milk protein yield $\div 6.38$.

${ }^{4}$ Plasma urea N. 
in products, active compounds, application levels, and experimental conditions (Benchaar et al., 2009). A general trend of decreasing ammonia concentration, but inconsistent effect on ruminal VFA appears from reviewing published studies (Benchaar et al., 2009). At higher doses, most EO products act as antimicrobials and inhibit ruminal fermentation, decreasing ammonia and VFA concentrations (Busquet et al., 2006; Benchaar et al., 2009).

This is the first study in which effects of OV have been evaluated in lactating dairy cows. Larger doses of oregano EO (300 and 3,000 mg/L) clearly inhibited ruminal fermentation in vitro (Busquet et al., 2006). A trend for increased acetate-to-propionate ratio and decreased propionate concentration, similar to the present experiment, was also observed in vitro by Cardozo et al. (2004) when supplementing $15 \mathrm{mg}$ of oregano EO/ $\mathrm{kg}$ of DM. This may be attributed to the low molecular weight of carvacrol and thymol, which have been shown to permeate and disrupt the cell membrane of grampositive bacteria that produce propionate (Sivropoulou et al., 1996). Wang et al. (2009) reported a significant increase in total VFA concentration, but no substantial changes in molar VFA proportions, in sheep receiving a commercial oregano EO product (Ropadiar; Ropapharm Int.).

The increase in ammonia- $\mathrm{N}$ concentration observed in this experiment is somewhat surprising as in most studies, EO have decreased ruminal ammonia concentration (Benchaar et al., 2009). Ammonia concentration was consistently higher for OV throughout the sampling period (data not shown), which is in line with the increased PUN concentration in the OV cows. Processes such as deamination of feed AA, microbial lysis, absorption, and microbial uptake regulate ammonia concentration in the rumen (Hristov et al., 2005b). The increased ammonia concentration observed with OV in this experiment could be attributed to the presence of carvacrol in oregano EO. Busquet et al. (2005b) reported in vitro that carvacrol decreased large peptide concentrations and increased ammonia-N concentrations 2 $\mathrm{h}$ after feeding. Despite the increased PUN, however, $\mathrm{OV}$ cows tended to have decreased urinary $\mathrm{N}$ losses, which may indicate better $\mathrm{N}$ utilization post-ruminally. This and the combination of numerically lower $\mathrm{N}$ intake and numerically greater milk yield resulted in greater efficiency of conversion of dietary $\mathrm{N}$ into milk protein for the OV treatment.

The decrease in ruminal methane production with OV was large in this study and, although in line with our in vitro results (Tekippe et al., 2010), was not supported by the ruminal fermentation and microbial profiles data. Most of the hydrogen gas formed during carbohydrate fermentation in the rumen is utilized by the methanogens to reduce carbon dioxide to methane (Wolin et al., 1997). Disposal of hydrogen is considered critical for efficient rumen fermentation and as propionate is an alternative to the hydrogen electron receptor, a strong inverse correlation exists between propionate formation and methane production in the rumen (Janssen, 2010). In the current experiment, it is not clear if propionate production and rate of absorption were affected as a result of the decrease in methane production by OV, although propionate concentration was not different between treatments. The relationship between methane production and rumen VFA is not always clear, even in a relatively simple-to-balance in vitro system. Busquet et al. (2005a), for example, reported a $75 \%$ decrease in methane concentration (batch culture experiment) with $300 \mathrm{mg}$ of garlic oil/L. At the same time the absolute propionate production was decreased; although concentration was slightly increased, the total VFA concentration was about $20 \%$ lower with the garlic oil treatment. A review of the effect of $\mathrm{EO}$ on ruminal fermentation did not report a clear relationship between rumen propionate and methane production (Hart et al., 2008). In other experiments, however, good agreement between propionate and methane production was found (Watanabe et al., 2010). Hydrogen concentrations were not measured in the current experiment, but accumulation of hydrogen in the rumen cannot be excluded as a consequence of the decreased methane production with OV (Garcia-Lopez et al., 1996; Kung et al., 2003). In a consequent experiment, we observed a significant increase in hydrogen concentration in rumen gas - 20 versus 54 to $70 \mathrm{mg} / \mathrm{m}^{3}$ (control and 3 levels of OV; Hristov et al., 2011) As pointed out by Janssen (2010), the processes of methane reduction and hydrogen accumulation are interrelated in the rumen. Thus, hypothetically it is possible that both increased propionate production and absorption and hydrogen accumulation occurred with the OV treatment in the current experiment. Information on these processes, however, was not collected.

The $\mathrm{SF}_{6}$ tracer method has been criticized for producing larger variability than established techniques for measuring methane production, such as respiration chambers. Clark (2010), for example, found good agreement in group mean methane emission measurements between $\mathrm{SF}_{6}$ and the chamber methods. Variability, however, was about twice as large for the $\mathrm{SF}_{6}$ method and the correlation between emission values obtained from individual animals and repeatability in the estimated rates was low (Clark, 2010; Pinares-Patiño et al., 2010). Indeed, the variability in our methane production data was large (Figure 1). This large variability may be partially due to variable methane emission rates following feeding (for most cows emissions increased after 
feeding), but was probably also a result of variability due to the $\mathrm{SF}_{6}$ technique. Various factors may have affected methane emission measurements in this study. Cécile et al. (2010), for example, reported lower (about $11 \%$ ) emission estimates with lower $\mathrm{SF}_{6}$ release rate tubes. The $\mathrm{SF}_{6}$ tracer may be retained within the digestive tract (Lassey et al., 2011), although this may be affecting less ruminal headspace than breath sampling sites, and may behave differently than the tracee gases (Pinares-Patiño et al., 2010). Extended sample collection periods may help decrease this variability (Gere et al., 2010; Lassey et al., 2011). The original $\mathrm{SF}_{6}$ method was developed for measuring enteric methane production in intact animals as an alternative to the chamber technique, where animals may behave differently than in their natural environment, which may affect enteric gas production rates (Johnson et al., 1994). Our approach in this and other studies (Hristov et al., 2009, for example) was to sample the ruminal headspace, assuming these samples would accurately represent eructated gas composition. Very few studies exist comparing rumen headspace and breath sampling. Cécile et al. (2010) found similar methane-emission rates between breath and ruminal headspace sampling methods using the $\mathrm{SF}_{6}$ technique (110 and $123 \mathrm{~L}$ vs. 101 and $114 \mathrm{~L}$, respectively). In contrast, Coates et al. (2010) found the $\mathrm{SF}_{6}$ procedure unsuitable for measuring enteric gas emissions from ruminally cannulated cattle. These authors, however, did not sample the rumen headspace directly, as in the current study, which undoubtedly affected their conclusions. The $\mathrm{SF}_{6}$ permeation tubes were left in the reticulorumen throughout the duration of the current experiment, which could have affected $\mathrm{SF}_{6}$ release rates. Indeed, emissions were lower $(P=$ $0.006)$ in period 2 versus period 1 of the trial $(19.3$ vs. $30.3 \mathrm{~g} / \mathrm{h}$, respectively; SEM = 8.21). However, no period by treatment interaction $(P=0.50)$ was found for the methane data. The reason for these decreased rates in period 2 cannot be determined, but it apparently did not affect our comparative results and overall conclusions. Nevertheless, due to the large variability in methane emissions within cow during the sampling cycle and between cows on the same treatment, the effect of OV on methane production reported here has to be interpreted with caution. Our measurements covered only a period of $8 \mathrm{~h}$ after feeding. We did not collect information on methane production during the remaining $16 \mathrm{~h}$ of the feeding cycle. Thus, we cannot be certain that the effect of OV persisted during the entire $24 \mathrm{~h}$ until the next day feeding. In addition, the OV was dosed into the rumen as a pulse dose at the time of feeding, thus most likely having larger effect on methane production during the period when methane data were collected. It is expected that methane production will be most intensive after feeding (methane production peaks within 1 to $2 \mathrm{~h}$ after feeding; Crompton et al., 2010) and it is likely that our data covered the period of the feeding cycle with the most intensive methane production. The effect of OV beyond the $8 \mathrm{~h}$ of sampling is not known. It has to be pointed out, however, that the cows had access to and consumed feed most of the day, except for the time they were milked and exercised (about $3 \mathrm{~h} / \mathrm{d}$ ). Nevertheless, cows tend to consume more feed when it is freshly delivered (DeVries and von Keyserlingk, 2005). In agreement with this, data by Crompton et al. (2010) suggest that methane production in dairy cows fed ad libitum peaks shortly after feeding (at $140 \mathrm{~min}$ in their case) and steadily decreases (at a rate of $-0.0007 / \mathrm{min}$ ) thereafter. Some ruminal bacteria can adapt to EO compounds (McIntosh et al., 2003) and, therefore, the effect of rumen fermentation modifiers must be verified in long-term experiments. Others have also reported antimethanogenic effects of oregano EO. Wang et al. (2009), for example, observed a $12 \%$ decrease in methane production in the rumen of sheep treated with a commercial product based on oregano EO.

It is likely that the effect of $\mathrm{OV}$ on methanogenesis observed in vitro by Tekippe et al. (2010) and in the current study is due to a combination of compounds in the oregano plant. Apart from volatile EO, oregano contains many bioactive compounds such as di- and tri-terpenoids, lipids and fatty acids, phenols, phenolic and hydroxycinnamic acids, quinones, and particularly, flavonoids (Skoula and Harborne, 2002). Many of these compounds have been shown to have antimicrobial properties (Baričevič and Bartol, 2002) and may also suppress ruminal archaea. The high antioxidant capacity of the oregano leaves used in this study supports this possibility. For example, the $\mathrm{ORAC}_{\mathrm{TAC}}$ of the oregano leaves, most likely due to its high flavonoids content, was from 4 to 12 times higher than the ORAC $_{\mathrm{TAC}}$ of conventional forages, such as the fresh tops of trefoil $\left(\right.$ ORAC $\left._{\mathrm{TAC}}=330\right)$, lespedeza $\left(\mathrm{ORAC}_{\mathrm{TAC}}=530\right)$, and dried alfalfa hay $\left(\mathrm{ORAC}_{\mathrm{TAC}}=172 \mu \mathrm{mol}\right.$ of TE/g; Ferreira, 2009). The $\mathrm{ORAC}_{\text {lipo }}$ values of OV were also higher than the $\mathrm{ORAC}_{\text {lipo }}$ usually obtained for conventional forage legumes and grasses such as lespedeza $\left(\mathrm{ORAC}_{\text {lipo }}\right.$ $=9.28)$ and fescue $\left(\mathrm{ORAC}_{\text {lipo }}=18.5 \mu \mathrm{mol}\right.$ of $\left.\mathrm{TE} / \mathrm{g}\right)$. This high $\mathrm{ORAC}_{\text {lipo }}$ usually indicates the presence of EO components such as thymol and carvacrol.

Origanum vulgare spp. EO composition vastly differs between plants grown in different regions and climatic conditions, but generally the most biologically important compounds are thymol, carvacrol, $p$-cymene, and linalool (Vokou et al., 1993; Baser, 2002). Carvacrol was the main EO compound of the oregano used in this experiment. At $1.4 \%$ EO in OV DM, the concentration 
of carvacrol can be estimated at $12.7 \mathrm{~g} / \mathrm{kg}$ of OV DM. Thus, at $500 \mathrm{~g} / \mathrm{d}(450 \mathrm{~g}$ of DM) dietary supplementation, the cows received about $5.7 \mathrm{~g}$ of carvacrol/d, which would correspond to about $57 \mathrm{mg} / \mathrm{L}$, assuming a 100-L rumen content volume (and instantaneous consumption of the compound). We conducted an in vitro screening experiment to identify the antimethanogenic effect of the predominant compounds in oregano (procedures were similar to Tekippe et al., 2010). Of the 16 individual compounds screened, several (thymol, carvacrol, and geraniol) linearly decreased methane production within application rates of 400 to $4,000 \mathrm{mg} / \mathrm{L}$ final medium concentration. Several other compounds had less pronounced effects (linalool, for example) and some ( $p$-cymene) had no effect on methane production. Carvacrol at $400 \mathrm{mg} / \mathrm{L}$ decreased methane production by $45 \%$ and completely inhibited it at $2,000 \mathrm{mg} / \mathrm{L}$. These high concentrations cannot be practical for in vivo conditions and the effects observed in vitro cannot be reliably extrapolated to the live animal. Factors such as duration of feed (or feed supplement) consumption and ruminal turnover rate additionally make these comparisons difficult. Nevertheless, the observed level of methane inhibition in this study suggests that (1) carvacrol is not the only bioactive compound in OV having inhibitory effect on rumen methanogenesis, or (2) longer adaptation may be required for manifestation of the effect of carvacrol. It is certainly possible that the effect of $\mathrm{OV}$ is due to a combination of effects of several compounds acting synergistically and perhaps requiring longer treatment adaptation period. Lambert et al. (2001), for example, combined thymol with carvacrol and observed higher antibacterial activity than either compound supplied separately. The effect of carvacrol, as a major compound of several EO, on rumen fermentation has been studied both in vitro and in vivo. Benchaar et al. (2007) reported that oregano oil $(200 \mathrm{mg} / \mathrm{L})$, or carvacrol $(400 \mathrm{mg} / \mathrm{L})$ depressed in vitro DM or NDF degradability with no apparent effects on VFA production or molar ratios. Chaves et al. (2008) supplemented lamb diets with $0.2 \mathrm{~g}$ of carvacrol $/ \mathrm{kg}$ of DM (which would approximately correspond to the carvacrol concentration in the OV diet in this experiment), and found no effects on rumen fermentation, or lamb performance. Similar lack of effect on rumen fermentation was reported by the same group in continuous culture (Chaves et al., 2009). Methane production was not measured in these experiments, but an earlier attempt (Chiquette and Benchaar, 2005) reported a significant decrease in methane production by 225 to $250 \mathrm{mg}$ of carvacrol/L in vitro. Concentrations below $225 \mathrm{mg} / \mathrm{L}$, however, had no effect on methane production, which is in support of the hypothesis that oregano $\mathrm{EO}$, or carvacrol, were only partially responsible for the methane inhibition effect observed with oregano leaves in this experiment.

In spite of the significant decrease in ruminal methane production, no differences were observed in archaeal diversity in this experiment. In an earlier study, no effect of coconut oil or lauric acid existed on methanogen-specific DGGE banding patterns despite significantly lower methane production with coconut oil (Hristov et al., 2009). Long-term monensin supplementation decreased methane production by $7 \%$ (expressed as $\mathrm{g} / \mathrm{d}$ ), but when the diversity of methanogens was determined using DGGE targeting the methanogen 16S rRNA gene, no significant change was observed in the banding patterns (Hook et al., 2009). In the same study, the abundance of methanogens, as determined by using real-time PCR, was not affected by treatment. In the current study, no effect of OV on apparent NDF digestibility or VFA concentration in the rumen was found, suggesting no toxic effect of OV on fibrolytic bacteria, which are the main bacterial hydrogen producers in the rumen. It is possible that the inhibition of methane production by OV may have been due to a disruption in interspecies hydrogen transfer between fibrolytic bacteria and methanogens rather than a direct toxic effect on methanogens. It also has to be pointed out that the molecular techniques used in this study are not strictly quantitative (Amend et al., 2010) and we cannot be certain that treatments did not affect the size of the bacterial or archaeal populations.

The OV supplement had no effect on intake, or total tract digestibility of nutrients in the current experiment. We are not aware of other studies on the effect of OV on nutrient digestibility in cattle. Ropadiar (a commercial product based on oregano EO; Ropapharm Int.) supplemented to a sheep diet at $250 \mathrm{mg} / \mathrm{d}$ had no effect on total tract apparent digestibility of nutrients (Wang et al., 2009).

This is the first report characterizing the response of milk production, composition, and feed efficiency with OV supplementation. Other published research evaluated individual EO, including oregano, or EO active compounds. Spanghero et al. (2009), for example, fed a microencapsulated blend of EO that included oregano EO and found no effect on milk production or component yields. However, these authors reported a numerical trend for increased milk fat concentration. The significant effect on milk fat concentration and yield in the current study may be attributable to slight shifts in microbial fermentation in the rumen, evident in the numerical increase in acetate-to-propionate ratio in the OV treatment. The fat concentration and yield increase, paired with a numerical increase in milk production, resulted in a trend for increased 3.5\% FCM yield for the OV diet. As methane production constitutes 
about 2 to $12 \%$ gross energy loss in cattle (Johnson et al., 1994), the trend for increased FCM yield may be partially attributed to increased metabolizable energy supply as a result of decreased methane production by OV. It has to be pointed out, however, that hydrogen not converted into VFA may also represent an energetic loss to the cow.

The oregano fed to the cows in this experiment had no effect on the organoleptic characteristics of milk. Sensory differences are typically seen in milk from animals consuming feeds that contain plant terpenes, which are the major component of EO. Thymol, for example, is a monoterpene. These compounds pass easily into milk (Viallon et al., 2000), causing off flavors. Thymol, however, was not found in EO from the OV used in this experiment.

\section{CONCLUSIONS}

Supplementation of dairy cow diet with $500 \mathrm{~g}$ of oregano leaves/d increased milk fat percentage, yield, and $3.5 \% \mathrm{FCM}$ feed efficiency and tended to increase $3.5 \%$ FCM yield. Due to a combination of insignificant, but unidirectional effects, the efficiency of transfer of feed $\mathrm{N}$ and $\mathrm{NE}_{\mathrm{L}}$ into milk protein and $\mathrm{NE}_{\mathrm{L}}$ was also increased by the oregano treatment. Ruminal fermentation effects of the oregano were subtle, except ammonia concentration was increased, which resulted in increased plasma urea $\mathrm{N}$ concentration. We observed a sizable decrease in rumen methane production with the oregano supplementation within $8 \mathrm{~h}$ after feeding; this effect, however, has to be interpreted with caution due to the large within- and between-animal variability in methane emission estimates. The oregano supplement was introduced into the rumen as a pulse dose at the time of feeding, thus most likely having a larger effect on methane production during the period when methane data were collected. Methane production is unlikely to be affected to the same extent throughout the entire feeding cycle.

\section{ACKNOWLEDGMENTS}

The authors thank Keith Lassey (National Institute of Water and Atmospheric Research, Wellington, NZ) for providing the $\mathrm{SF}_{6}$ permeation tubes, P. Topper (Department of Agricultural and Biological Engineering, Pennsylvania State University, University Park) for analyzing the gaseous emission potential of manure, Charles Cantrell (Natural Products Utilization Research Unit, USDA-ARS National Center for Natural Products Research, University, MS) for analyzing the oregano essential oil composition, John Hayes and the Sensory Evaluation Center (Department of Food Sci- ence, Pennsylvania State University) for performing the milk sensory tests, Scot Dowd (Research and Testing Laboratory, Texas Tech University, Lubbock) for performing the rumen microbial profile analyses, and the staff of the Department of Dairy and Animal Science Dairy Center (Pennsylvania State University) for their conscientious care of the experimental cows.

\section{REFERENCES}

Adams, R. P. 2009. Identification of Essential Oil Components by Gas Chromatography/Mass Spectrometry. 4th ed. Allured Publishing Corp., Carol Stream, Illinois.

Amend, A. S., K. A. Seifert, and T. D. Bruns. 2010. Quantifying microbial communities with 454 pyrosequencing: does read abundance count? Mol. Ecol. 19:5555-5565.

Bakkali, F., S. Averbeck, D. Averbeck, and M. Idaomar. 2008. Biological effects of essential oils-A review. Food Chem. Toxicol. 46:446-475.

Baričevič, D., and T. Bartol. 2002. The biological/pharmacological activity of the Origanum genus. Pages 177-213 in Oregano: The Genera Origanum and Lippia. S. E. Kintzios, ed. Taylor and Francis, London, UK and New York, NY.

Baser, K. H. C. 2002. The Turkish Origanum species. Pages 109-126 in Oregano: The Genera Origanum and Lippia, S. E. Kintzios, ed. Taylor and Francis, London, UK and New York, NY.

Bates, D. M., and D. G. Watts. 1988. Nonlinear Regression Analysis and Its Applications. John Wiley \& Sons Inc., New York, NY.

Benchaar, C., A. V. Chaves, G. R. Fraser, Y. Wang, K. A. Beauchemin, and T. A. McAllister. 2007. Effects of essential oils and their components on in vitro rumen microbial fermentation. Can. J. Anim. Sci. 87:413-419.

Benchaar, C., A. N. Hristov, and H. Greathead. 2009. Essential oils as feed additives in animal nutrition. Pages 111-146 in Phytogenics in Animal Nutrition. T. Steiner, ed. Nottingham University Press, Nottingham, UK.

Bentayeb, K., P. Vera, C. Rubio, and C. Nerin. 2009. Adaptation of the ORAC assay to the common laboratory equipment and subsequent application to antioxidant plastic films. Anal. Bioanal. Chem. 394:903-910.

Bodas, R., S. López, M. Fernandez, R. Garcia-González, A. B. Rodríguez, R. J. Wallace, and J. S. González. 2008. In vitro screening of the potential of numerous plant species as antimethanogenic feed additives for ruminants. Anim. Feed Sci. Technol. 145:245-258.

Borchers, R. 1965. Proteolytic activity of rumen fluid in vitro. J. Anim. Sci. 24:1033-1038.

Burt, S. 2004. Essential oils: Their antibacterial properties and potential applications in foods-A review. Int. J. Food Microbiol. 94:223-253.

Busquet, M., S. Calsamiglia, A. Ferret, M. D. Carro, and C. Kamel. 2005a. Effect of garlic oil and four of its compounds on rumen microbial fermentation. J. Dairy Sci. 88:4393-4404.

Busquet, M., S. Calsamiglia, A. Ferret, and C. Kamel. 2005b. Screening for the effects of natural plant extracts and secondary plant metabolites on rumen microbial fermentation in continuous culture. Anim. Feed Sci. Technol. 123/124:597-613.

Busquet, M., S. Calsamiglia, A. Ferret, and C. Kamel. 2006. Plant extracts affect in vitro rumen microbial fermentation. J. Dairy Sci. 89:761-771.

Cardozo, P. W., S. Calsamiglia, A. Ferret, and C. Kamel. 2004. Effects of natural plant extracts on protein degradation and fermentation profiles in continuous culture. J. Anim. Sci. 82:3230-3236.

Cécile, M., J. Koolaard, Y. Rochette, H. Clark, J. P. Jouany, and C. S. Pinares-Patiño. 2010. Effect of release rate of the $\mathrm{SF}_{6}$ tracer on methane and carbon dioxide emission estimates based on ruminal and breath gas samples. Page 85 in Proc. 4th Int. Conf. Greenhouse Gases Anim. Agric., Banff, AB, Canada. E. J. McGeough and S. M. McGinn, ed. 
Chaney, A. L., and E. P. Marbach. 1962. Modified reagents for determination of urea and ammonia. Clin. Chem. 8:130-132.

Chaves, A. V., I. Schei, Y. Wang, T. A. McAllister, and C. Benchaar. 2009. Effects of carvacrol and cinnamaldehyde on microbial fermentation when added to a barley- or corn-based diet in a continuous-culture system. Can. J. Anim. Sci. 89:97-104.

Chaves, A. V., K. Stanford, L. L. Gibson, T. A. McAllister, and C. Benchaar. 2008. Effects of carvacrol and cinnamaldehyde on intake, rumen fermentation, growth performance, and carcass characteristics of growing lambs. Anim. Feed Sci. Technol. 145:396-408.

Chiquette, J., and C. Benchaar. 2005. Effects of different dose levels of essential oils compounds on in vitro methane production by mixed ruminal bacteria. J. Dairy Sci. 88(Suppl. 1):306. (Abstr.)

Clark, H. 2010. Animal vs. measurement technique variability in enteric methane production-Is the measurement resolution sufficient? Page 77 in Proc. 4th Int. Conf. Greenhouse Gases Anim. Agric. Banff, AB, Canada. E. J. McGeough and S. M. McGinn, ed.

Coates, T., B. Farr, K. A. Beauchemin, and S. M. McGinn. 2010 Can the $\mathrm{SF}_{6}$ tracer gas technique be used to accurately measure methane production from ruminally cannulated cattle? Page 86 in Proc. 4th Int. Conf. Greenhouse Gases Anim. Agric., Banff, AB, Canada. E. J. McGeough and S. M. McGinn, ed.

Cowan, M. M. 1999. Plant products as antimicrobial agents. Clin Microbiol. Rev. 12:564-582.

Crompton, L. A., J. A. N. Mills, C. K. Reynolds, J. France, D. Sauvant, J. van Milgen, P. Faverdin, and N. Friggens. 2010. Fluctuations in methane emission in response to feeding pattern in lactating dairy cows. Pages 176-180 in Proc. 7th Int. Workshop Modelling Nutrient Digest. Utilization Farm Anim., Paris, France. Wageningen Academic Publishers, Wageningen, the Netherlands.

Dehority, B. A. 1993. Laboratory Manual for Classification and Morphology of Rumen Ciliate Protozoa. CRC Press Inc., Boca Raton, FL.

DeVries, T. J., and M. A. G. von Keyserlingk. 2005. Time of feed delivery affects the feeding and lying patterns of dairy cows. J. Dairy Sci. 88:625-631.

Dowd, S. E., T. R. Callaway, Y. Sun, T. McKeehan, R. G. Hagevoort, and T. S. Edrington. 2008a. Evaluation of the bacterial diversity in the feces of cattle using bacterial tag-encoded flx amplicon pyrosequencing (bTEFAP). BMC Microbiol. 8:125-132.

Dowd, S. E., Y. Sun, P. R. Secor, D. D. Rhoads, B. M. Wolcott, G. A. James, and R. D. Wolcott. 2008b. Survey of bacterial diversity in chronic wounds using pyrosequencing, DGGE, and full ribosome shotgun sequencing. BMC Microbiol. 8:43-58

Dragland, S., H. Senoo, K. Wake, K. Holte, and R. Blomhoff. 2003 Several culinary and medicinal herbs are important sources of dietary antioxidants. J. Nutr. 133:1286-1290.

Ferreira, J. F. S. 2009. Artemisia species in small ruminant production: Their potential antioxidant and anthelmintic effects. Pages 53-70 Appalachian Workshop and Research Update: Improving small ruminant grazing practices M. Morales, ed. Mountain State University/USDA, Beaver, WV.

Foley, A. E., A. N. Hristov, A. Melgar, J. K. Ropp, R. P. Etter, S. Zaman, C. W. Hunt, K. Huber, and W. J. Price. 2006. Effect of barley and its amylopectin content on ruminal fermentation and nitrogen utilization in lactating dairy cows. J. Dairy Sci. 89:4321-4335

Garcia-Lopez, P. M., L. Kung Jr., and J. M. Odom. 1996. In vitro inhibition of microbial methane production by 9,10 -anthraquinone. J. Anim. Sci. 74:2276-2284.

Gere, J. I., K. E. Williams, R. Gratton, M. P. Juliarena, and C. S. Pinares-Patiño. 2010. The $\mathrm{SF}_{6}$ tracer technique for methane emission estimation: The normalized mixing ratio of $\mathrm{SF}_{6}$ across days of breath sampling. Page 90 in Proc. 4th Int. Conf. Greenhouse Gases Anim. Agric., Banff, AB, Canada. E. J. McGeough and S. M. McGinn, ed.

Greathead, H. 2003. Plants and plant extracts for improving animal productivity. Proc. Nutr. Soc. 62:279-290.

Hart, K. J., D. R. Yáñez-Ruiz, S. M. Duval, N. R. McEwan, and C. J. Newbold. 2008. Plant extracts to manipulate rumen fermentation. Anim. Feed Sci. Technol. 147:8-35.
Hook, S. E., K. S. Northwood, A. D. Wright, and B. W. McBride. 2009. Long-term monensin supplementation does not significantly affect the quantity or diversity of methanogens in the rumen of the lactating dairy cow. Appl. Environ. Microbiol. 75:374-380.

Hristov, A. N., M. Ivan, L. M. Rode, and T. A. McAllister. 2001 Fermentation characteristics and ruminal ciliate protozoal populations in cattle fed medium- or high-concentrate barley-based diets. J. Anim. Sci. 79:515-524.

Hristov, A. N., C. Lee, T. Cassidy, K. Heyler, J. A. Tekippe, G. A Varga, and B. Corl. 2011. Effect of Origanum vulgare L. leaves on production and milk fatty acid composition in lactating dairy cows. J. Dairy Sci. 94(E-Suppl. 1):135.

Hristov, A. N., T. A. McAllister, D. R. Ouellet, and G. A. Broderick. 2005a. Comparison of purines and nitrogen-15 as microbial flow markers in beef heifers fed barley- or corn-based diets. Can. J. Anim. Sci. 85:211-222.

Hristov, A. N., J. K. Ropp, K. L. Grandeen, S. Abedi, R. P. Etter, A. Melgar, and A. E. Foley. 2005b. Effect of carbohydrate source on ammonia utilization in lactating dairy cows. J. Anim. Sci. 83:408-421.

Hristov, A. N., M. Vander Pol, M. Agle, S. Zaman, C. Schneider, P. Ndegwa, V. K. Vaddella, K. Johnson, K. J. Shingfield, and S. K. R. Karnati. 2009. Effect of lauric acid and coconut oil on ruminal fermentation, digestion, ammonia losses from manure, and milk fatty acid composition in lactating cows. J. Dairy Sci. 92:55615582 .

Huhtanen, P., K. Kaustell, and S. Jaakkola. 1994. The use of internal markers to predict total digestibility and duodenal flow of nutrients in cattle given six different diets. Anim. Feed Sci. Technol. 48:211-227.

Janssen, P. H. 2010. Influence of hydrogen on rumen methane formation and fermentation balances through microbial growth kinetics and fermentation thermodynamics. Anim. Feed Sci. Technol. 160:1-22.

Jayanegara, A., N. Togtokhbayar, H. P. S. Makkar, and K. Becker. 2009. Tannins determined by various methods as predictors of methane production reduction potential of plants by an in vitro rumen fermentation system. Anim. Feed Sci. Technol. 150:230-237.

Johnson, K. A., M. T. Huyler, H. H. Westberg, B. K. Lamb, and P. Zimmerman. 1994. Measurement of methane emissions from ruminant livestock using a $\mathrm{SF}_{6}$ tracer technique. Environ. Sci. Technol. $28: 359-362$.

Kamra, D. N., N. Agarwal, and L. C. Chaudhary. 2006. Inhibition of ruminal methanogenesis by tropical plants containing secondary compounds. Int. Congr. Ser. 1293:156-163.

Kovats, E. 1965. The retention index system. Pages 229-247 in Advances in Chromatography. J. C. Giddings and R. A. Keller, ed. Marcel Dekker Inc., New York, NY.

Kung, L., Jr., K. A. Smith, A. M. Smagala, K. M. Endres, C. A Bessett, N. K. Ranjit, and J. Yaissle. 2003. Effects of 9,10 anthraquinone on ruminal fermentation, total-tract digestion, and blood metabolite concentrations in sheep. J. Anim. Sci. 81:323-328.

Lambert, R. J. W., P. N. Skandamis, P. J. Coote, and G.-J. E. Nychas. 2001. A study of the minimum inhibitory concentration and mode of action of oregano essential oil, thymol and carvacrol. J. Appl. Microbiol. 91:453-462.

Lassey, K. R., C. S. Pinares-Patiño, R. J. Martin, G. Molano, and A. M. S. McMillan. 2011. Enteric methane emission rates determined by the SF6 tracer technique: Temporal patterns and averaging periods. Anim. Feed Sci. Technol. 166-167:183-191.

NRC. 2001. Nutrient Requirements of Dairy Cattle. 7th rev. ed. National Academy Press, Washington, DC.

Matsuura, H., H. Chiji, C. Asakawa, M. Amano, T. Yoshihara, and J. Mizutani. 2003. DPPH radical scavengers from dried leaves of oregano (Origanum vulgare). Biosci. Biotechnol. Biochem. 67:2311-2316.

McIntosh, F. M., P. Williams, R. Losa, R. J. Wallace, D. A. Beever, and C. J. Newbold. 2003. Effects of essential oils on ruminal microorganisms and their protein metabolism. Appl. Environ. Microbiol. 69:5011-5014. 
Pinares-Patiño, C. S., K. R. Lassey, R. J. Martin, G. Molano, M. Fernandez, S. MacLean, E. Sandoval, D. Luo, and H. Clark. 2010. Validation of the $\mathrm{SF}_{6}$ tracer technique for estimation of methane emission from sheep using respiration chambers. Page 100 in Proc. 4th Int. Conf. Greenhouse Gases Anim. Agric., Banff, AB, Canada. E. J. McGeough and S. M. McGinn, ed.

Prior, R. L., H. Hoang, L. Gu, X. Wu, M. Bacchiocca, L. Howard, M. Hampsch-Woodill, D. Huang, B. Ou, and R. Jacob. 2003. Assays for hydrophilic and lipophilic antioxidant capacity (oxygen radical absorbance capacity $\left(\mathrm{ORAC}_{\mathrm{FL}}\right)$ ) of plasma and other biological and food samples. J. Agric. Food Chem. 51:3273-3279.

SAS Institute. 2003. SAS User's Guide: Statistics. SAS Inst. Inc., Cary, NC.

Sivropoulou, A., E. Papanikolaou, C. Nikolaou, S. Kokkini, T. Lanaras, and M. Arsenakis. 1996. Antimicrobial and cytotoxic activities of Origanum essential oils. J. Agric. Food Chem. 44:1202-1205.

Skoula, M., and J. B. Harborne. 2002. The taxonomy and chemistry of Origanum. Pages 67-108 in Oregano: The Genera Origanum and Lippia. S. E. Kintzios, ed. Taylor and Francis, London, UK and New York, NY.

Smith, D. 1981. Removing and analyzing total nonstructural carbohydrates from plant tissue. Wisconsin Agric. Exp. Stn. Rep. No. R 2107. University of Wisconsin, Madison.

Snell, F. D., and C. T. Snell. 1954. Amino acids. Pages 104-169 in Colorimetric Methods of Analysis. F. D. Snell, and C. T. Snell, ed. D. Van Nostrand Co. Inc., New York, NY.

Spanghero, M., P. H. Robinson, C. Zanfi, and E. Fabbro. 2009. Effect of increasing doses of a microencapsulated blend of essential oils on performance of lactating primiparous dairy cows. Anim. Feed Sci. Technol. 153:153-157.

Tekippe, J. A., A. N. Hristov, K. S. Heyler, V. D. Zheljazkov, J. Ferreira, and G. A. Varga. 2010. Effects of herbs and essential oils on in vitro batch culture ruminal fermentation. J. Dairy Sci. 93(Suppl. 1):175.

Valadares, R. F. D., G. A. Broderick, S. C. Valadares Filho, and M. K. Clayton. 1999. Effect of replacing alfalfa silage with high moisture corn on ruminal protein synthesis estimated from excretion of total purine derivatives. J. Dairy Sci. 82:2686-2696.

Van Soest, P. J., J. B. Robertson, and B. A. Lewis. 1991. Methods for dietary fiber, neutral detergent fiber, and nonstarch polysaccharides in relation to animal nutrition. J. Dairy Sci. 74:3583-3597.
Viallon, C., B. Martin, I. Verdier-Metz, P. Pradel, J.-P. Garel, J.-B. Coulon, and J.-L. Berdagué. 2000. Transfer of monoterpenes and sesquiterpenes from forages into milk fat. Lait 80:635-641.

Vokou, D., S. Kokkini, and J.-M. Bessiere. 1993. Geographic variation of Greek oregano (Origanum vulgare ssp. hirtum) essential oils. Biochem. Syst. Ecol. 21:287-295.

Wallace, R. J. 2004. Antimicrobial properties of plant secondary metabolites. Proc. Nutr. Soc. 63:621-629.

Wang, C. J., S. P. Wang, and H. Zhou. 2009. Influences of flavomycin, ropadiar, and saponin on nutrient digestibility, rumen fermentation, and methane emission from sheep. Anim. Feed Sci. Technol. 148:157-166.

Watanabe, Y., R. Suzuki, S. Koike, K. Nagashima, M. Mochizuki, R. J. Forster, and Y. Kobayashi. 2010. In vitro evaluation of cashew nut shell liquid as a methane-inhibiting and propionate-enhancing agent for ruminants. J. Dairy Sci. 93:5258-5267.

Wheeler, E. F., P. A. Topper, N. E. Brown, and G. A. Varga. 2007. Multiple-chamber steady-state gas emission detection from dairy manure slurry. CD-ROM Proc. Int. Symp. Air Quality Waste Management Agric. ASABE Publication Number 701P0907cd. American Society of Agricultural and Biological Engineers (ASABE), St. Joseph, MI.

Wolin, M. J., T. L. Miller, and C. S. Stewart. 1997. Microbe-microbe interactions. Pages 467-491 in The Rumen Microbial Ecosystem. P. N. Hobson and C. S. Stewart, ed. Blackie Academic \& Professional, London, UK.

Yang, C. M., Jr., and G. A. Varga. 1989. Effect of three concentrate feeding frequencies on rumen protozoa, rumen digesta kinetics, and milk yield in dairy cows. J. Dairy Sci. 72:950-957.

$\mathrm{Yu}, \mathrm{Z}$., and M. Morrison. 2004. Comparisons of different hypervariable regions of rrs genes for use in fingerprinting of microbial communities by PCR-denaturing gradient gel electrophoresis. Appl. Environ. Microbiol. 70:4800-4806.

Zheljazkov, V. D., A. Callahan, and C. L. Cantrell. 2008. Yield and oil composition of thirty-eight basil (Ocimum basilicum L.) accessions grown in Mississippi. J. Agric. Food Chem. 56:241-245. 